\title{
NEUROHISTOLOGICAL BASIS FOR THE FUNCTIONING OF PAIRED HALF-CENTERS
}

\author{
ERNEST RETZLAFF 1,2 \\ Physiology Laboratory, Dniversity of Michigan, Ann Arbor
}

FIFTEEN FIGURES

\section{METHODS}

Immersion or perfusion methods of fixation of tissue for histological studies are currently used in most laboratories. For special studies a freeze-dehydration process may be required. The value of any of these methods is determined only by its effectiveness in preserving the structures being studied. It is not necessary to employ a complex method, such as freeze-dehydration, if a more simple method will do. Frequently, several fixing and staining methods must be tried to determine which ones are the most useful. In this study it was found that neither immersion nor perfusion fixation would preserve complete axon collaterals and their synaptic endings. It was necessary to use a modified freeze-dehydration method to completely preserve these minute structures in the numbers required for a critical neurohistological study.

The criteria kept in mind during this investigation were: that the fresh tissue be fixed rapidly to prevent autolytic destruction of the minute neuronal structures; that the tissue be hardened only enough to allow serial sectioning of paraffin-embedded tissue; that both fixation and dehydration be completed in not more than 10 hours or so that the tissue

${ }^{1}$ Part of a dissertation submitted in partial fulfillment of the requirements for the degree of Doctor of Philosophy in the University of Michigan.

${ }^{2}$ This study was supported in part by a grant to Robert Gesell from the Rackham School of Graduate Studies, University of Michigan. 
could be stored at that time; that the process preserve the entire neurons with their axon collaterals and their synaptic endings; and that these structures be readily stained by a reduced-silver on-the-slide method.

The methods used for immersion and perfusion fixation of central nervous system tissue will be described briefly. The freeze-dehydration process will be described in detail, includa description of the apparatus constructed and used in this laboratory.

\section{Fixation: immersion and perfusion}

The commonly used method of immersing tissue in fixing solution was tried on both cold- and warm-blooded animals. These included the goldfish, the bullhead, the frog, the water snake, the hamster, the rat, the cat, and the dog. Generally, the results were unsatisfactory for this study because of imperfect preservation of axon collaterals and their synaptic endings. Frequently, the stained tissue showed unequal shrinkage or swelling, indicated by the fact that nerve-cell bodies were partially separated from the surrounding tissue.

Several fixing solutions were tried in order to determine which would produce the most satisfactory fixation of small slices of tissue. These included: (1) $37 \%$ formalin, $10 \mathrm{~cm}^{3}$, isotonic saline, $90 \mathrm{~cm}^{3}$; (2) $37 \%$ formalin, $10 \mathrm{~cm}^{3}$, isotonic saline, $80 \mathrm{~cm}^{3}$, chloral hydrate, $10 \mathrm{gm}$; (3) Bouin's solution containing $10 \%$ chloral hydrate; (4) Petrunkevitch's Brom-phenol-cupric solution ('43); (5) $10 \%$ formalin, $5 \mathrm{~cm}^{3}$, trichloroacetic acid, $2 \mathrm{gm}, 80 \%$ ethyl alcohol, $90 \mathrm{~cm}^{3}$; (6) $10 \%$ formalin, $5 \mathrm{~cm}^{3}$, glacial acetic acid, $5 \mathrm{~cm}^{3}, 80 \%$ ethyl alcohol, $90 \mathrm{~cm}^{3}$. Of the above solutions, the last 4 gave good gross-structure fixation but preserved only relatively few synaptic boutons.

The temperature of these solutions was varied from $0^{\circ} \mathrm{C}$. to $37^{\circ} \mathrm{C}$. in order to determine the effects of such differences. It was found that when the tissue removed from the anesthetized animal was placed immediately in fixing solution 
chilled to $0^{\circ} \mathrm{C}$., the preservation of the gross structure was better than when the material was fixed at room temperature or at $37^{\circ} \mathrm{C}$. In all cases the tissue was cut into slices not more than $4 \mathrm{~mm}$ in thickness, to assure rapid penetration of the fixing solution.

The method of first hardening the entire central nervous system of large animals in $10 \%$ formalin before cutting it into small pieces for further fixation resulted in imperfect preservation of most of the synaptic boutons. However, for a study of gross structure, nuclear pattern and fiber tracts, where some shrinkage is permissible, this method is very useful. When the brain and spinal cord of small fish were first hardened in Brom-phenol-cupric solution for 24 hours at $0^{\circ} \mathrm{C}$., many of the synapses were stainable. Complete axon collaterals could not be found in any tissue fixed by the immersion method.

Fixing of central nervous system tissue by perfusion through the circulatory system, as described by Bodian ('36), resulted in satisfactory preservation of the synapses only when an adequate perfusion was accomplished. The method employed was that of flushing the circulatory system with isotonic saline containing $10 \%$ chloral hydrate to remove the blood before perfusing with the fixing solution. The solutions were cooled to $0^{\circ} \mathrm{C}$. by passing them through a glass coil immersed in an ice-salt mixture. When the solutions were used either at room temperature or at $37^{\circ} \mathrm{C}$. for either coldor warm-blooded animals, the fixation was inferior to that obtained at $0^{\circ} \mathrm{C}$. The perfusion pressure was maintained by a gravity-type perfusion apparatus.

The procedure used for fish was to first chill them in ice water containing $10 \%$ chloral hydrate until quiescent; then the heart was exposed and the ventricle cannulated. Perfusion with the flushing solution was started immediately. When the fluid escaping from the cut auricle was free of blood, perfusion with the fixing solution was started. This was terminated when the fluid returning to the heart contained fixing solution. Unless a colored fixing solution was 
used, it was not possible to determine by inspection whether the entire brain and spinal cord had been completely perfused until the tissue was sectioned and stained. For studies on the frog and the snake, the animal was first anesthetized, using I. P. sodium pentobarbital (Lilly), $75 \mathrm{mg} / \mathrm{kg}$, before exposing and cannulating the heart. Flushing and fixing procedures were the same as described for the fish.

Warm-blooded animals such as the rat, the hamster, the dog, and the cat were anesthetized, using I. V. sodium pentobarbital, $45 \mathrm{mg} / \mathrm{kg}$. Small animals were perfused through the left ventricle. For studies on the brain tissue of the dog and the cat, a bilateral perfusing method by way of the common carotid arteries was used. Both carotids were connected to a single perfusing bottle using a $\mathrm{Y}$-tube near the animal to assure equal pressure to both sides of the brain. After the flushing was started, both carotids were ligated close to their origins to prevent back-flow of the solution. The jugular veins were opened to allow escape of the perfusate, which prevented distortion of the tissue by excess pressure. These perfusions were carried out at a pressure approximately $10 \mathrm{~mm} \mathrm{Hg}$ above the mean blood pressure of the animal. The solutions were chilled to $0^{\circ} \mathrm{C}$. by use of the glass coil previously described. When both brain and spinal cord were to be fixed, it was necessary to perfuse the entire circulatory system by way of the aorta. The femoral veins were cannulated to allow escape of the perfusate.

The brain and the spinal cord were removed from the animal as soon as the fixation was completed. Great care must be exercised during this removal because the fixed tissue may easily be damaged by bending or stretching. The desired tissue was cut into small pieces, not over $5 \mathrm{~mm}$ in thickness, placed in the same solution as that used for perfusion, and after 8 hours at $0^{\circ} \mathrm{C}$. the tissue was transferred to a dehydrating solution.

The 4 fixing solutions which produced the best results by the immersion method also were satisfactory for the perfu- 
sion methods. However, Bouin's solution containing $10 \%$ chloral hydrate resulted in the best preservation of the synaptic endings.

The methods of dehydration for both immersion- and perfusion-fixed tissues included use of graded alcohols followed by xylene, S-127 (Esso Oil Co., New Orleans, La.), 1-4 dioxane (Eastman Co., Rochester, N. Y), and Technicon dehydrant (Technicon Chemical Co., New York, N. Y.). The last three methods were satisfactory for nervous tissue, with the best results obtained by use of 4 changes of Technicon dehydrant at two-hour intervals. The tissue may be stored in this solution with no apparent damage.

Bioloid paraffin (Will Corporation, Rochester, N. Y.) and Tissuemat (Fisher Scientific Co., St. Louis, Mo.) were used for infiltration and embedding media. Tissuemat proved to be more desirable than paraffin. Frequently the paraffin had a melting point different from that indicated on the container. Also, bubble formation in the tissue was never present when Tissuemat was utilized. The infiltration was accomplished by placing the dehydrated tissues in the embedding medium kept just at its melting point in a constant-temperature oven. Four changes at one-hour intervals produced complete infiltration. The tissues were embedded in small paper cups which then were floated on ice water to facilitate cooling.

All tissues were serial-sectioned at thicknesses of $5 \mu$ to $30 \mu$. The ribbons were cut into slide-length segments and mounted serially on albuminized slides, using the water-bath flotation method. The slides were dried in a blower-type drier. The sections could be stained with protargol immediately.

\section{Freeze-dehydration}

A high-vacuum dehydrator (fig. 1, A to C) of all-metal construction was designed and built in this larobatory. Descriptions of this type of apparatus have been published by Gersh ('32), Mendlow and Hamilton ('50), and Glick and Malmstrom ('51). 
Description of apparatus. The vacuum pumps were a mechanical forepump, two-stage electrical motor-driven Cenco Hyvae (Central Scientific Co., Chicago, III.) and an oil diffusion pump (2), air-eooled, all metal, model D-P, type VMF, size 4, (Vacuum Equipment Division, Distillations Products Co., Rochester, N. Y.). Silicone diffusion pump fluid 702 (Dow-Corning Corp., Midland, Mich.) was used because of its great stability. After 140 operations this fluid had not suffered any apparent deterioration.

A McLeod mercury gauge, ealibrated to measure pressure from 0.1 to $100 \mu \mathrm{Hg}$., was used in the system. This unit was mounted on a fixed plywood backing with a lucite cover to protect it from breakage. At the high-vacuum side of the gauge, a trap surrounded by a $500 \mathrm{~cm}^{3}$ Dewar flask filled with dry ice-acetone mixture, was used to prevent distillation of mereury into the metal system.

The connection ( 1 ) between the diffusion pump and the forepump was made of high vacuum rubber tubing, $2 \mathrm{~cm}$ I.D. Two chrome-plated brass "flush elbows" (3), $4.5 \mathrm{~cm}$ I.D., joined by a Cenco vacuum coupling, No. 94235 (4), formed the connecting pipe (3) between the diffusion pump and the specimen chamber (13). The cover $(10), 14 \mathrm{~cm}$ in diameter, was made of $12 \mathrm{~mm}$ nickel-plated brass. A gasket seat, $3 \mathrm{~cm}$ deep, was cut into its under surface for a molded neoprene gasket, $7 \mathrm{~mm} \times 12 \mathrm{~cm}$ (11). Four holes were drilled in the cover, one $(4.5 \mathrm{~cm})$ for the pipe (3) and three $(1.8 \mathrm{~cm})$ for the two Cenco vacuum connectors, No. 94270 (6 and 8), and the Cenco vacuum release valve, No. 94270 (5). The specimen chamber (13), $10 \mathrm{~cm}$ in diameter and $10 \mathrm{~cm}$ deep, made from an aluminum desiccator bottom, was supported by a nickel-plated brass ring, $14 \mathrm{~cm}$ in diameter (12). The seal (fig. 1, B) between the eover and the chamber was obtained by approximation of the flat lip (13a) to the cover with the neoprene gasket (11) interposed. Six bolts (14) with wing nuts (15) were employed to complete the seal. The 6 equally spaced bolt holes are indicated by 17 in figure 1 , C. The cold-thimble condenser (7) was made from a pyrex glass bulb, $8 \mathrm{~cm}$ in diameter, with the bottom pushed inward. A vacuum connector (6) provided a vacuum-tight seal for the neck of the condenser. The chamber was conneeted with the MeLeod gauge using a similar vacuum connector (8), a short length of glass tubing and high-vacuum rubber tubing (9). A vacuum release valve (5) was used to break the vacuum when required. The cover was supported by two stainless steel rods (16). The specimen chamber was cooled with a suitable solution contained in a wide-mouth Dewar flask, $15 \mathrm{~cm}$ in diameter and $30 \mathrm{~cm}$ deep (not shown in diagram).

The two types of tissue containers are shown in figures $1, D$ and $E$. The tissue baskets (fig. 1, D), measuring $2 \times 2 \times 2 \mathrm{~cm}$, were of thin perforated stainless steel. A spring-wire holder was useful to lift these baskets. The cups for direct paraffin embedding (fig. 1, E) were constructed from $3 \mathrm{~cm}$ lengths of brass tubing $3 \mathrm{~cm}$ in diameter. A brass disk with a $5 \mathrm{~mm}$ hole in the center was soldered into one end. These were then nickel-plated.

In all permanent metal connections, stainless steel solder (X-cell Super X, Hewitt Co., Detroit, Mich.) was used. The rubber-to-metal connections were tightly clamped with thumbscrew radiator-hose clamps, using silicone grease to complete the seal. 
Procedure. The tissue cups (fig. 1, E) were prepared by first coating the inner surface with silicone vacuum grease to prevent the embedding medium from adhering to the metal. A small cotton plug was used to close the hole in the
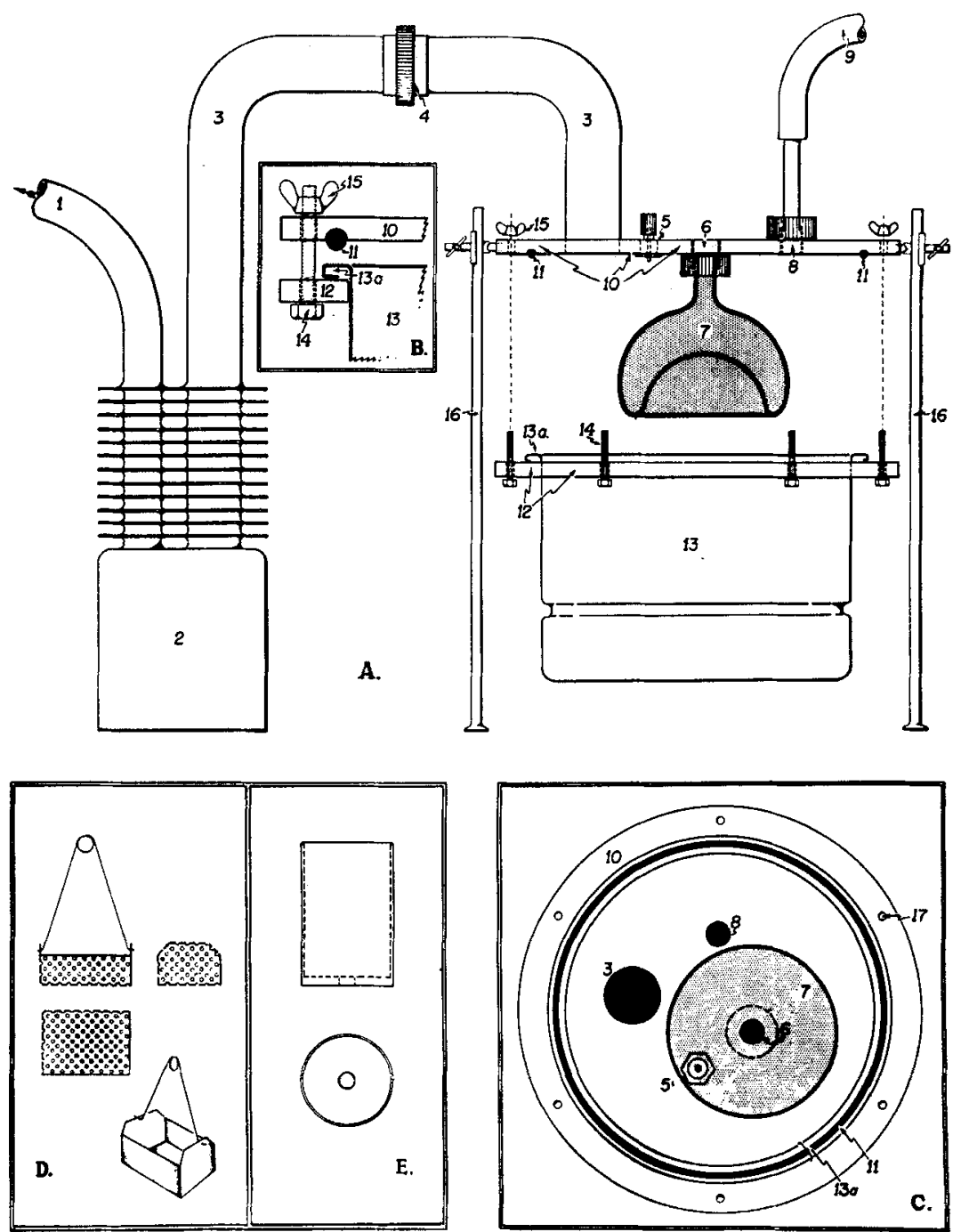

Fig. I (A) Freeze-dehydration apparatus; (B) detail drawing of chamber to-cover seal; (C) bottom surface of chamber cover; (D) tissue basket and handle; (E) tissue eup. 
bottom of the cup. The cups were half filled with Tissuemat $\left(52-54^{\circ} \mathrm{C}\right.$.) and transferred to the dehydration chamber (13). The system was sealed and the forepump started. The paraffin in the cups was melted by warming the chamber with hot water. At the pressure attained by the forepump (100 $\mu$ ), the degassing operation was completed in 10 minutes. The paraffin was hardened while under vacuum, using dry iceacetone mixture for the cooling medium. This took about 5 minutes. The cups were stored in a desiccator cooled in dry ice until used.

Pieces of freshly removed tissue, not over $3 \mathrm{~mm}$ in thickness, were dropped into a small beaker half filled with liquid isopentane at $-80^{\circ} \mathrm{C}$. (Eastman Co., Rochester, N. Y.). After three minutes had elapsed, the beaker was then partially immersed in liquid nitrogen. The isopentane was agitated to assure rapid heat dispersal. In approximately 30 seconds, the tissue was frozen. Using chilled forceps, the frozen tissues were transferred to the tissue cups, which had been cooled to about $-73^{\circ} \mathrm{C}$., and then stored in a covered desiccator cooled in a dry ice-acetone mixture until the desired amount of tissue was frozen. Care must be taken to handle the freezing containers and the tissue cups with long forceps or with wire cup holders to avoid injury to the fingers.

For dehydration, the tissue cups were placed in the precooled dehydration chamber which was elevated into place and bolted to its cover. The forepump and the diffusion pump were started at once. To provide cooling, the Dewar flask, partially filled with dry ice-acetone mixture, was elevated to surround the dehydration chamber.

After approximately 15 minutes, the pressure decreased to $50 \mu$. As soon as the fins of the diffusion pump were hot, the electric fan was turned on. The pressure decreased to $1 \mu$ after a total of 30 minutes. At that time the cold-thimble condenser was filled with liquid nitrogen. In one hour after the system is sealed the pressure will fall to $0.1 \mu$ and be maintained at this level throughout the remainder of the operation period. At the end of the second hour the dry ice- 
acetone mixture in the Dewar flask was changed to dry iceethyl oxalate mixture to maintain a temperature of $-40^{\circ} \mathrm{C}$.

During the entire operation the only attention required was the addition of liquid nitrogen to the cold thimble, and an occasional replenishment of dry ice for the cooling chambers. Hourly checks were made to determine the pressure level.

After 7 hours, the cooling mixture for the specimen chamber was replaced with hot water in a glass beaker maintained at $60^{\circ} \mathrm{C}$. by a small immersion-type electric heater. Fifteen minutes were required to melt the paraffin and to completely infiltrate the tissue. The diffusion pump heater was turned off at that time. The chamber was then chilled, using the cooling mixture to harden the paraffin. This took about 10 minutes. The forepump was stopped, the vacuum broken by opening the vent (5) and the embedded tissues removed.

The paraffin blocks were loosened from the cups by slightly warming them in hot water to separate the paraffin from the metal. A wooden dowel, inserted into the hole in the bottom of the cup, was used to push out the block.

These unfixed tissues were sectioned serially, at any required thickness, mounted on chemically clean albuminized slides and dried in an oven at $40^{\circ} \mathrm{C}$. If sections less than $15 \mu$ were required, it was helpful to coat the outer surface of the block with melted paraffin before each section was cut. This coating provided a firm support for the sections, which then were easily fixed to an albuminized slide by firm pressure of a metal spatula. The paraffin was removed from the sections by immersing the slides in petroleum ether. The petroleum ether was removed by two changes of absolute ethyl alcohol. Fixation of these tissues was by Bouin's solution containing $10 \%$ chloral hydrate, for one hour.

A method found more useful in this study was one in which the tissues were fixed before embedding. The tissues were processed as before, except that metal baskets (fig. 1, D) were used to hold them. When the dehydration was completed, the tissues were transferred directly to the fixing 
solution, dehydrated, and then embedded. The two fixing solutions found satisfactory for the dehydrated tissues were Bouin's solution made with absolute ethyl alcohol in place of water with the addition of chloral hydrate (10\%), and absolute ethyl alcohol containing $10 \%$ chloral hydrate. The tissues were fixed for a minimum of 4 hours at $0^{\circ} \mathrm{C}$, but could be left overnight. Dehydration was by Technicon dehydrant, 4 changes at one-hour intervals. Embedding was in Tissuemat. These tissues were serial-sectioned at any desired thickness and mounted as before.

The tissues processed by freeze-dehydration were stained by the protargol method of Bodian ('37a). This method consistently stained the axon collaterals and their synaptic endings. The need for thorough washing of the slides after their removal from protargol, as suggested by Rogers ('52), was found to improve the results. His suggestion of an additional silver impregnation using dilute silver nitrate reduced the contrast so that it was difficult to follow the course of the minute axon collaterals.

Attention is again called to the fact that protargol imported and packaged by the Winthrop Chemical Company prior to about 1942 or Protargol-S for staining (WinthropStearns, Inc., New York 13, N. Y.) was found to produce consistently good staining of the minute structural elements of nervous tissue. The latter material is now certified by the Biological Stain Commission.

A counterstain useful to clearly define the cells bodies was $0.01 \%$ aqueous acridine yellow (Schultz No. 602, National Aniline and Chemical Co., New York, N. Y.). The slides were stained for a minimum of 30 minutes in a freshly made solution, which was most effective when used before the protargol-stained tissues were dehydrated. Alcohol and xylene treatment apparently interfered with the selective staining action of the acridine yellow.

\section{Discussion}

In this study it was found that neither immersion nor perfusion fixation of central nervous system tissue would 
satisfactorily preserve the axon collaterals and their synaptic endings. Although it was possible to stain many of the synapses in tissue well fixed by the perfusion method, it was never possible to completely stain more than a small percentage of these delicate structures when the immersion method was used. Apparently, autolytic changes taking place before the tissue was completely permeated by the fixing solution were responsible for the destruction of the synapses. In no instance was it possible to find completely preserved axon collaterals using either of these methods.

The excellent preservation of the minute structures of the central nervous system attained by use of the freeze-dehydration method described in this paper indicates that the process is valuable for use in a critical neurohistological study. The relatively low cost and the simplicity of construction and operation make this type of apparatus a desirable adjunct to any tissue laboratory.

Frequently, tissue processed by the freeze-dehydration method is found to have large vacuoles throughout. This vacuole formation may be prevented by maintaining the dehydration chamber temperature near $-73^{\circ} \mathrm{C}$. with dry iceacetone mixture during the first two hours of operation. After this initial period the dehydration chamber temperature was raised to $-40^{\circ} \mathrm{C}$, using dry ice-ethyl oxylate, for the remainder of the operation time. It is also essential that the tissue be kept at a temperature not higher than $-73^{\circ} \mathrm{C}$. until dehydration is started. There was vacuole formation in tissue stored at temperature warmer than $-40^{\circ} \mathrm{C}$. prior to dehydration. It may be that these vacuoles are caused by a relative thawing of the tissue, either during storage or in the early stages of water removal.

The cold-thimble condenser located over the frozen tissue provided a cold surface to refreeze the water as it is removed from the tissue. This thimble increases the pumping speed of the system greatly. To test their efficiency, Drierite (W. A. Hammond Drierite Co., Xenia, Ohio) was placed in the dehydration chamber and the water trap. The system was 
operated as before, but with no liquid nitrogen in the thimble. After 48 hours of continuous operation, at $0.1 \mu \mathrm{Hg}$ pressure, pieces of brain tissue $3 \mathrm{~mm}$ thick were not dehydrated, which indicates the effectiveness of the cold thimbles.

A McLeod gange was employed in determining the pressure level of the system. No attempt was made to measure the water-vapor pressure, a procedure frequently suggested as a means of determining the degree of dehydration of the tissue.

Fixation of the dehydrated tissues immediately after their removal from the dehydrator was found to be most satisfactory for preservation of the minute structural elements. The fixing solutions were made as nearly anhydrous as possible to avoid needless hydration of the tissue. When the modified Bouin's solution or the alcohol-chloral hydrate solution was used, the tissues were hardened to an optimal degree for sectioning.

\section{OBSERVATIONS}

According to the Gesell theory ('40) of central nervous system function a constant current, self-engendered in the nerve cell, flows internally from dendrites to axon hillock and externally from axon hillock to dendrites. The source of this current is an existing metabolic gradient between the dendrites, a region of high activity, and the axon, a region of low activity. The high resistance of the neuraxon diverts the current through the neuromembrane, into the external circuit. The dendrites, being highly electronegative, absorb this current. Thus, the cell functions as an electrochemical generator of a constant subthreshold centrogenic current of metabolic origin.

In addition to the centrogenic neurocellular current, the afferent impulses impinging on the dendrites and perikaryon provide another source of eurrent by the production of local negativity at the synaptic endings, which serves to increase the potential in proportion to the number of these impulses. The quantitative variation of afferent synaptic driving forces tends to function as a reflexogenic 
regulator of neuronal activity. If the sum of the centrogenic current and the afferent reflexogenic current increases above the threshold for excitation, the nerve cell will discharge. Inhibition may resolve itself into a decrease in potential produced by inhibitory afferents ending on a region including and adjacent to the axon hillock, designated as the inhibitory pole. This decrease in potential-difference causes the neuron to stop discharging. Accordingly, the afferent impulses to the dendrites and most of the perikaryon are excitatory, and those to the regions adjacent to and including the axon hillock are inhibitory. This divides the neuron into excitatory and inhibitory functional regions, suggesting a polar function of the neuron.

It is further suggested by Gesell's theory that three types of recurrent axon collaterals serve to mediate and integrate the activity of the central nervous system. These are reenforcing, recruiting, and inhibitory collaterals. The reenforcing collaterals function as a mechanism for acceleration of the neuron discharge. While the neuron is sending impulses down its axon, the collaterals return impulses to the dendrites, which increases the electronegativity of the excitatory pole. The augmented negativity increases the potentialdifference and, in turn, the rate of discharge. This feed-back is repeated again and again as long as the combined centrogenic and reflexogenic current is of threshold strength

The recruitment of a series of neurons of similar function into an augmenting type of response may be mediated through the recruiting collaterals. These collaterals originating from the axon of the first of a series of neurons pass to the excitatory pole of a second neuron. The axon collaterals of the second neuron extend to the excitatory pole of a third. By this means, the first cell having reached a threshold level of excitation will discharge and excite the second neuron by way of recruiting collaterals, which in the same way excite a third. Cessation of discharge of the first cell withdraws stimulation from the second, and thus sets into play a successive deactivation. 
The proposed role of inhibitory collaterals is that of prevention of simultaneous discharge of antagonistic neurons; thus the activation of one half-center cell automatically inhibits its antagonist, and thereby causing a coordinated alternating activity. According to the Gesell theory when one cell of a pair is subjected to synaptic driving forces in excess of those forces acting on the other cell the first cell will discharge. This discharge will serve to activate its end organ as well as to inhibit the discharge of the opposing (or second) cell since inhibitory collaterals of the first cell ending on the axon pole of the second cell decrease the latter's potentialdifference. This relationship then may be reversed, and the first cell may be inhibited while the second cell is activated.

\section{Mauthner's cells}

The massive paired Mauthner's cells of fish provide ideal neurons for the analysis of the relation of structure to funetion. The shape of these cells (plate 1, figs. 14 and 15) is generally that of a spindle bent at the middle to form a right angle, with the two limbs formed by the ventral and lateral dendrites. The ventral dendrite, of which there may be more than one in some teleosts, branches as it courses ventrally. The lateral dendrite extends nearly to the entering root of the VIIIth nerve. Also, there are several dendrite-like structures at the region of the axon hillock, which are called cap dendrites. The axon arises as a mesial extension of the cell, turns caudally, and decussates with its fellow to continue down the cord.

The distribution of the various types of synaptic endings suggests, in agreement with Gesell's theory ('40) of polar function of the neuron, that the excitatory pole consists of the dendrites and the major portion of the perikaryon; the inhibitory pole includes the part of the perikaryon bordering the axon hillock, the hillock, and the proximal region of the axon.

The axon pole of Mauthner's cell is surrounded by a collar-like cap, which was first described by Mayser (1882), and 
later by Beccari ('07). Bartelmez ('15) noted that this structure is formed by terminal axon branches and their synapses. Bodian's studies ('37b) indicated that this cap consists of a central spiral core of fine unmyelinated fibers, as well as the outer coarse-fiber spiral previously described by Bartelmez. The central-core fibers end as small spherical enlargements which are restricted to the perikaryon bordering the

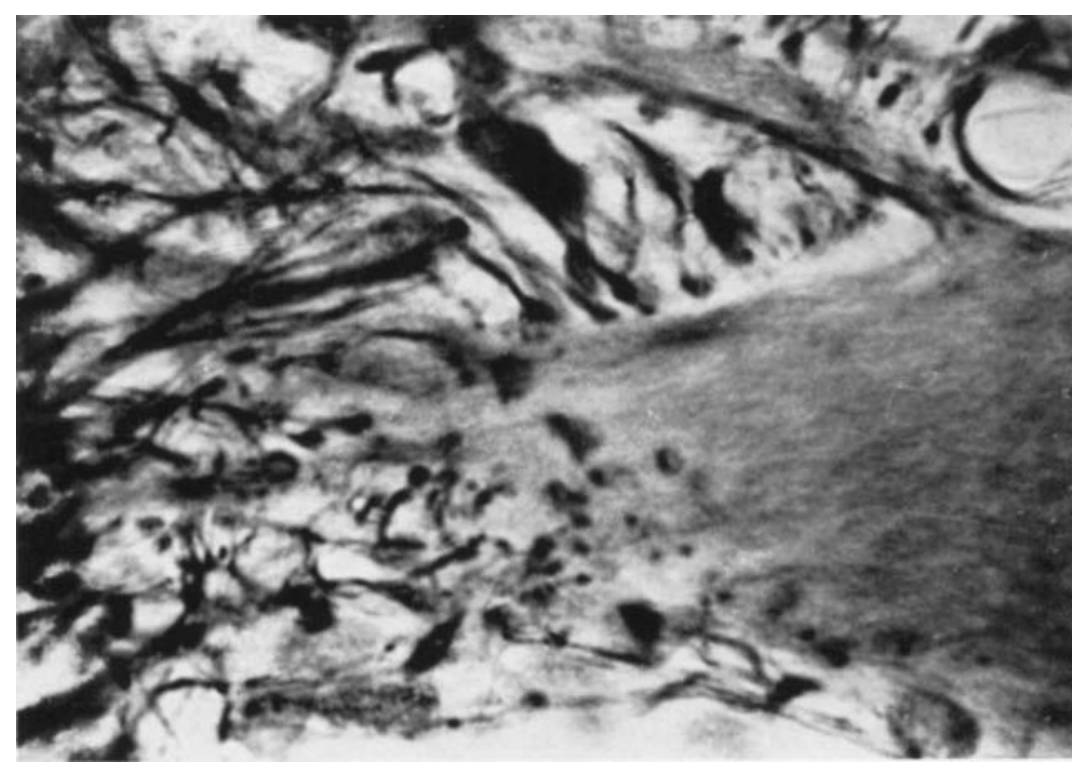

Fig. 2 Axon hilloek region of Mauthner's cell of the bullhead showing large and small end-feet. Note the three end-feet on the cap-dendrite at the upper right corner. Freeze-dehydration, modified Bouin fixative, protargol stain. $\times 2800$.

axon hillock, the hillock, and the proximal part of the axom (fig. 2). Also, some of these synapses are evident on the cap dendrites (fig. 2). The heavy fibers of the peripheral spiral of the cap end as unmyelinated clubs on the axon hillock and the proximal portion of the axon.

The terminal endings of the VIIIth nerve root fibers on the excitatory pole of one Mauthner's cell and the inhibitory pole of the other provide for simultaneous reflex excitation of one cell and reflex inhibition of the other (fig. 3). These 


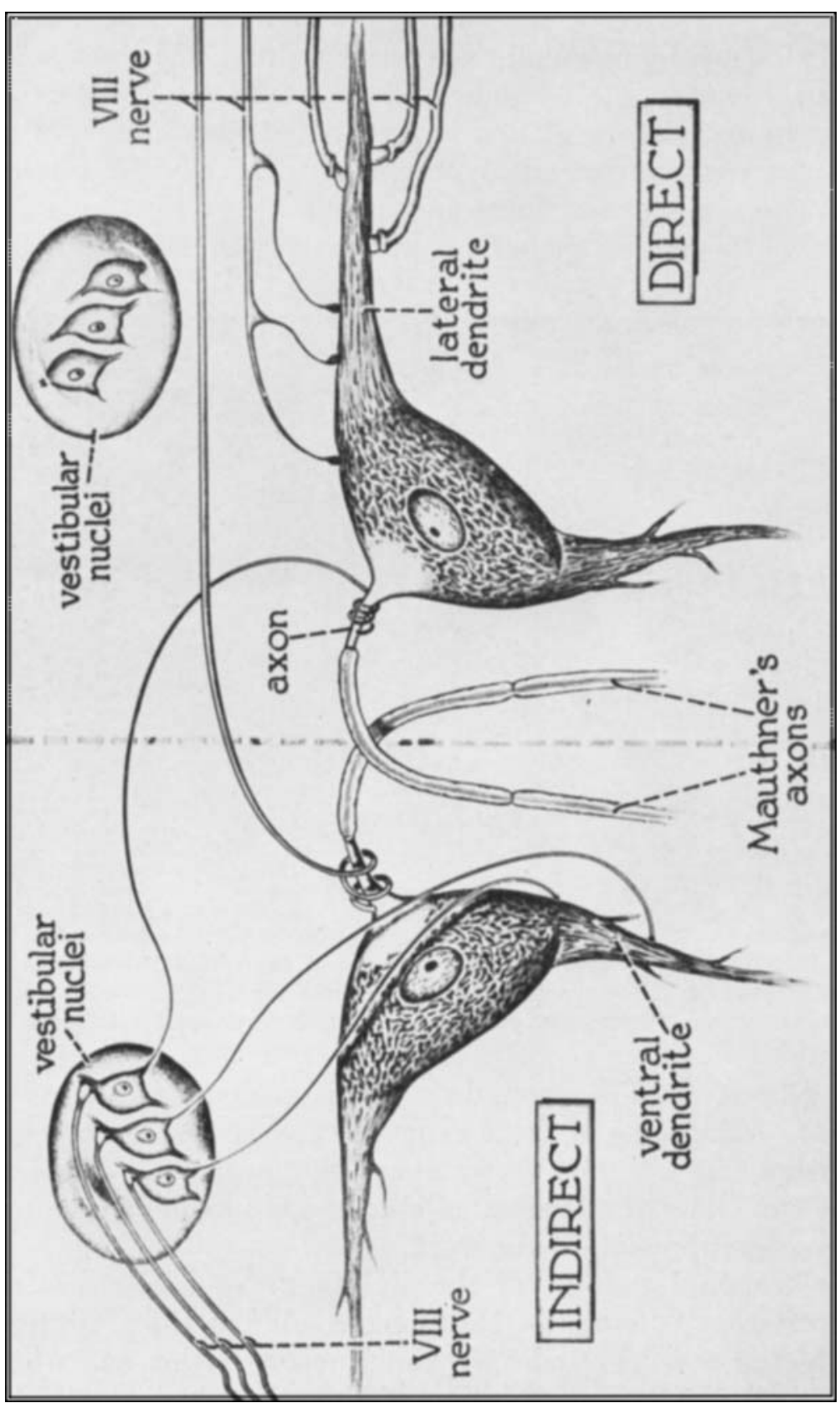

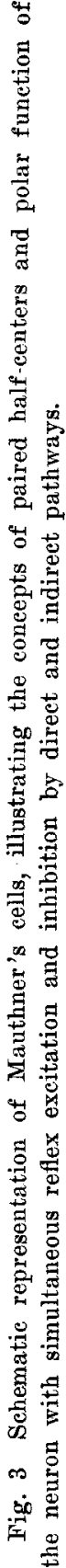


root fibers not only synapse directly on the Mauthner's cells, but accomplish an indirect connection by way of the tangential nucleus and Deiters' nucleus, which together constitute the vestibular nuclei in fish (Ariëns Kappers, Huber and Crosby, '36, I, p. 454). These two pathways, direct and indirect, to the Mauthner's cell may provide the structural relationships

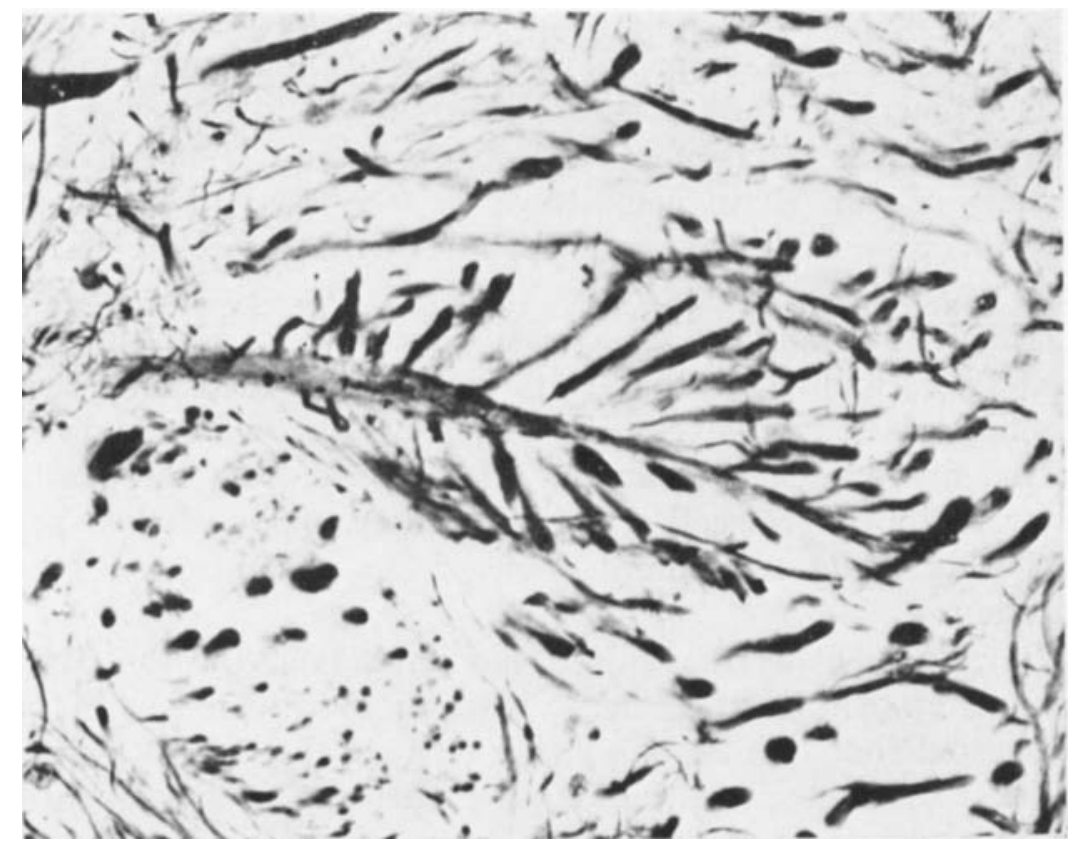

Fig. 4 Large myelinated club-like synaptic endings on the lateral dendrite of Mauthner's cell of the bullhead. Freeze-dehydration, modified Bouin fixative, protargol stain. $\times 1800$.

required for powerful reflex response of the fish to sensory stimuli.

In our preparations, the direct VIIIth nerve root fibers appear to end on rather specific functional regions of the Mauthner's cell. These fibers, according to Bartelmez and Hoerr ('33), and Bodian ('37b), synapse as large myelinated and large unmyelinated cıabs. In our own preparations, these myelinated club-like endings of the VIIIth nerve fibers have 
been demonstrated mainly on the distal portions of the lateral dendrite of the homolateral Mauthner's cell (fig. 4). The VIIIth nerve fibers crossing to the opposite side form the coarse component of the axon cap, which synapse as unmyelinated clubs, limited to the axon pole of the contralateral Mauthner's cell (fig. 3). Another example of regional distribution of synapses is evidenced by the termination of the VIIIth nerve axons as large unmyelinated clubs on the perikaryon and on the proximal portion of the lateral dendrite of the homolateral Mauthner's cell but not on the axon pole of this cell, as Bartelmez ('15) suggested.

This neuron chain constituted by the VIIIth nerve, the Mauthner's cell, and the appropriate segmental motor neuron may provide a direct pathway for integration of reflex activity of the fish in response to external stimuli. The VIIIth nerve root fibers ending on the excitatory pole of the homolateral Mauthner's cell will excite it reflexogenically, while the decussating fibers synapsing on the inhibitory pole of the contralateral Mauthner's cell will inhibit its activity. Thus, provision is made for simultaneous reflex excitation and inhibition.

Bartelmez ('15) recognized the importance of the direct connection of the VIIIth nerve with the Mauthner's cells. He suggested that this system could activate the fish to a rapid reflex response. The direct reflex pathway, a three-neuron chain, consists of VIIIth nerve fibers, Mauthner's cell, and the motor cells of the spinal cord. He considered this to represent a minimum-length neuron chain which would provide a means for a rapid and powerful reflex response. Perhaps even more important than the length of this neuron chain is the morphology of the neurons involved. According to the theory of neurocellular generation of current (Gesell, '40), the massive Mauthner's cell, acting as the source of a self-engendered centrogenic current, plus the strong reflexogenic synaptic drive originating both directly from the VIIIth nerve and indirectly by way of the vestibular nuclei, should provide a powerful sustained driving force to excite the spinal 
motor neurons. In addition, the large-diameter medullated axons should tend to increase the conduction speed.

The indirect connections of the VIIIth nerve with Mauthner's cells, by way of the vestibular nuclei, is over fibers which appear to end on the medial surface of the ventral dendrite and the perikaryon of the homolateral cell, as well as on the axon pole of the contralateral Mauthner's cell (fig. 3 ). According to Bartelmez ('15), the afferents to the ventral dendrites arise from the ventral acoustic nucleus, the chief $V$ th nucleus, the tectum, through the crossed and the noncrossed tecto-bulbar tracts, and the cerebellum, by way of the cerebello-tegmental system. The synapses of these fiber's consist of large and small end-feet and a few club-like endings. 'Their distribution is almost exclusively to the medial surface of the ventral dendrite and the perikaryon, as was reported by Bodian ('37b).

The synaptic endings seen on the perikaryon are small and large end-feet, as well as the previously mentioned large unmyelinated clubs (fig. 5). Only a few unmyelinated clublike endings terminate on the cell body. The fine fibers arising from the infracommissural bundle of the medial longitudinal fasciculus appear to end on the perikaryon near the axon hillock (figs. 2, 15) by means of both small and large end-feed. Bodian suggested that these fibers might also end on the cap dendrites, which was evident in our preparations.

The central spiral-core of the axon cap, according to Bodian, may represent axon terminal branchings homologous with those described by Herrick ('14) and Bartelmez ('15) as coming from the midbrain by way of the medial longitudinal fasciculus. Bodian suggested that this central spiral may represent an inhibitory mechanism similar to that proposed by Coghill ('34) for inhibition of the motor neurons of the spinal cord by synaptic endings of Mauthner's axon.

\section{Spinal motor cells}

The axon-cap structure is not unique to Mauthner's cell. A similar structure has been described by Pitzorno ('13, '14) 
in the ciliary gangtion of Selachians and Chelonians. In some of our preparations of the bullhead spinal cord, a funnelshaped collar of fine fibers, resembling an axon cap, appears to surround the axon pole of some of the ventral-horn motor cells. This collar, although not so extensive as that seen in relation to Mauthner's cells, apparently consists of a spiral of minute unmyelinated terminal fibers of the axon which end as small spherical synapses on the axon hillock area. Their function here again may be inhibitory to the motor-cell discharge.

Coghill ('34) observed that the terminal collaterals of Mauthner's axon frequently end on the axons of both spinal motor cells and intercalated cells. He suggested that these synapses excite some of the motor cells and, at the same time, inhibit reflexes mediated through the intercalated neurons. In the bullhead we have observed that terminal collaterals of an axon may end on the dendrites of one motor cell and on the axon-hillock region, as an axon spiral collar, on an adjacent motor neuron. It may be that this relationship is another example of simultaneous reflex excitation and inhibition evident in relation to the spinal motor neurons.

\section{Pyramidal cells}

This study of the pyramidal cells of the motor cortex is made in an attempt to correlate their histological structure with certain functions of the cerebral cortex. Of particular interest is the demonstration of axo-axonic collaterals (figs. 5,6 ), which may function as an inhibitory mechanism. These collaterals differ from those described by Ramón y Cajal ('11,

Fig. 5 Pyramidal cell of dog motor cortex. Axon of adjacent motor cell (upper arrow) gives rise to inhibitory collateral which ends on the axon of the pyramidal cell (lower arrow). Axon and collateral have been slightly darkened. Freeze-dehydration, modified Bouin fixative, protargol stain, $\times 1400$.

Fig. 6 Axon collateral ending near axon hillock of pyramidal cell of dog motor cortex (upper arrow). Pyramidal cell axon ending as large end-foot (lower arrow) on the perikaryon of an adjacent motor cell. Axon and collateral have been slightly darkened. Freeze-dehydration, absolute alcohol-chloral hydrate fixative, protargol stain. $\times 2600$. 

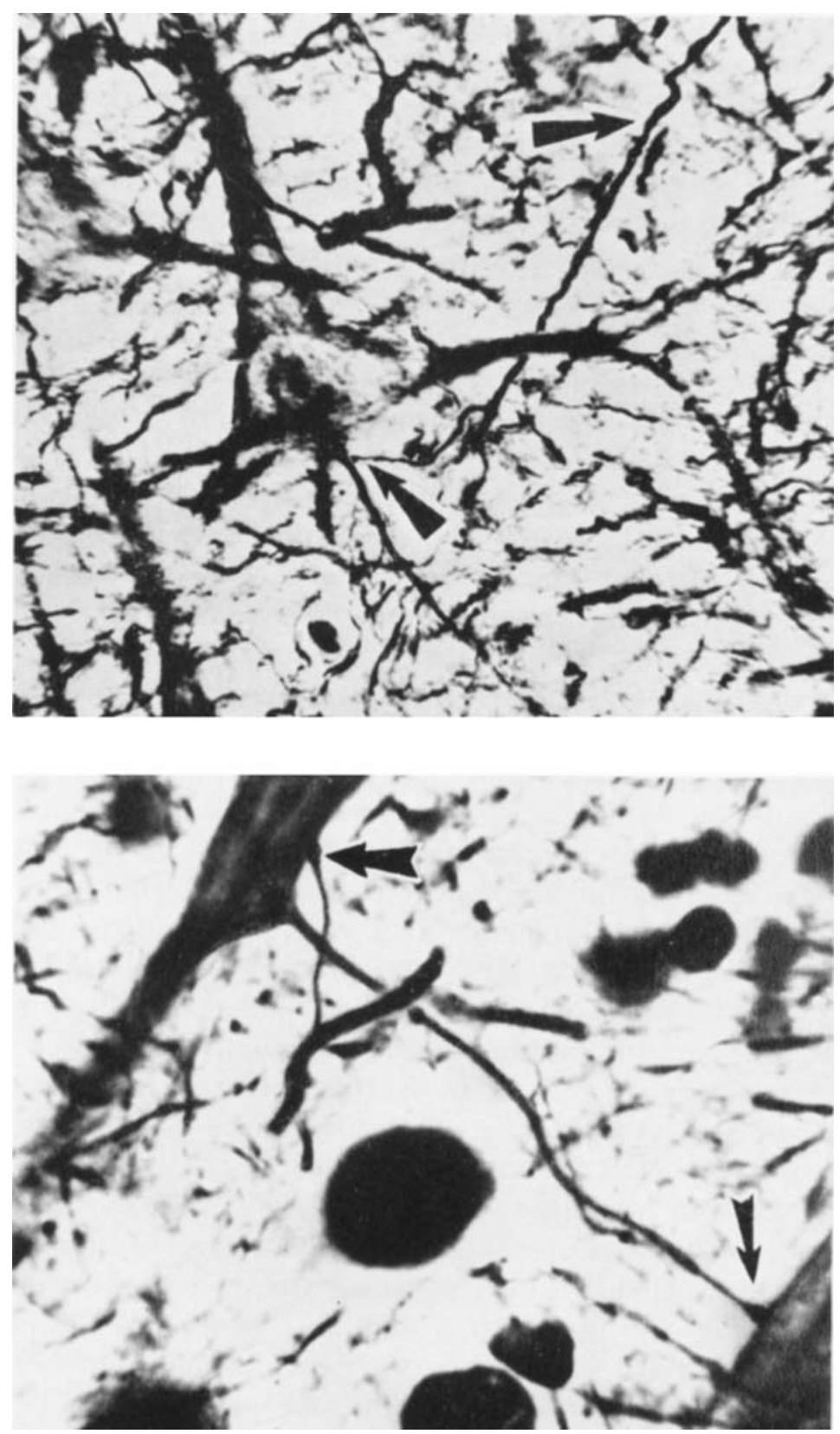

Figures 5 and 6 
p. 535) in that they terminate on the axon pole of an adjacent pyramidal cell.

In cortical tissue of $\mathrm{dog}$ and cat prepared by the freezedehydration method and stained with protargol, the typical shape of these cells is that of an elongated pyramid with the apex prolonged by a long branched dendrite (fig. 5). Other dendritic processes arise from the basal angles of the pyramid as well as from the other surfaces of the cell. The dendrites in these preparations are relatively smooth, thus differing from their appearance as indicated by Ramón $\mathbf{y}$ Cajal ('11, p. 644), but like those seen in Golgi's Atlas (1894, pl. 8). A long, thin axon originates from the conical axon hillock at the base of the pyramidal cell (fig. 5) or from one of the dendrites (fig. 6); a short distance from its origin the axon often increases in diameter, as Ramón y Cajal ('11) suggested for the neuraxons of other cells. There are slight constrictions at irregular intervals along its length.

In our preparations, the synaptic endings on the pyramidal cells are of three general types. There are small fibers ending with only slight terminal enlargements; larger fibers with large, elongated bulb-like endings and loop-like synapses. The third type, which was reported by Ramón y Cajal ('11, p. 559), the endings on the dendrites and the perikaryon, are mainly minute enlargements and loop-like synapses; those on the axon hillock or the proximal part of the axon are usually in the form of slight terminal enlargements (figs. 5, $6)$. Since synaptic endings are found on the dendrites and on the perikaryon, as well as on the axon pole of the pyramidal cells, excitatory and inhibitory poles may be recognized on these cells as on Mauthner's cells.

Organization of the pyramidal cells of the cerebral cortex into pairs of neurons or half-centers, as suggested by Gesell ('40), would provide a central integrating mechanism of the highest order for the control of motor function. The halfcenter concept proposes that two neurons may function as a pair with each controlling an opposing muscle action. Thus, while one muscle is contracted, its antagonist is relaxed, as 
in flexion or extension of the arm. Each half-center neuron, having a self-engendered neurocellular current and being further influenced by the afferent synaptic driving forces to its excitatory pole, would activate its end-organ whenever the threshold is reached. Believing that neurocellular excitation may be caused by an increased neurocellular potentialdifference between excitatory and inhibitory poles of the neuron, Gesell ('40) also proposed that inhibition may resolve itself into a decreased potential-difference. Accordingly, when the synaptic forces impinge on the region designated as the inhibitory pole, there may be a reduction in this potentialdifference, and the frequency of discharge may diminish.

The pyramidal cells in area 4 of the mammalian cerebral cortex are considered to be the highest level of the central nervous system for the integration required to accomplish purposeful muscular movements. These motor cells are influenced by afferents from subcortical regions of the nervous system, as well as by association fibers from other cortical areas. The end results of these stimuli to the pyramidal cells are the movements such as those used in walking, or in other complex motor functions. All movements, from the gross type to the most highly developed manual skills, require that certain muscle groups or individual muscles be active while others are relatively inactive. Unless this is accomplished, a disorganized activity pattern will result. It is suggested that certain intercellular connections exist so that when one neuron is exciting its end-organ it is also inhibiting a neuron controlling an opposing action. This may be the role of the axo-axonic inhibitory collaterals. These collaterals extending between the two neurons of opposing action would cause an alternating discharge of each of the neurons of a pair.

\section{Müller's and reticular cells}

In the medulla oblongata of fishes, examples of recurrent collaterals are evident. A reenforcing collateral originating as a slight conical elevation on the axon of one Müller's cell 
extends to the perikaryon and a dendrite of the same cell (fig. 7); a collateral of this same type was found passing from the axon of a reticular cell to one of its dendrites (fig. 8). An inhibitory axo-axonic collateral arising from a heavily myelinated axon of one reticular cell ends on the proximal portion of the axon of a like neuron (fig. 9). Also, in the fish medulla, a collateral fiber arising from a descending axon terminates on the axon hillock of a reticular cell. Not only will this collateral inhibit the discharge of the reticular cell upon which it ends, but its descending axon may excite (or inhibit) the spinal motor neuron(s) which represents its chief termination. Thus, simultaneous excitation of the spinal motor neuron (or neurons) and inhibition of the reticular cell(s) may occur.

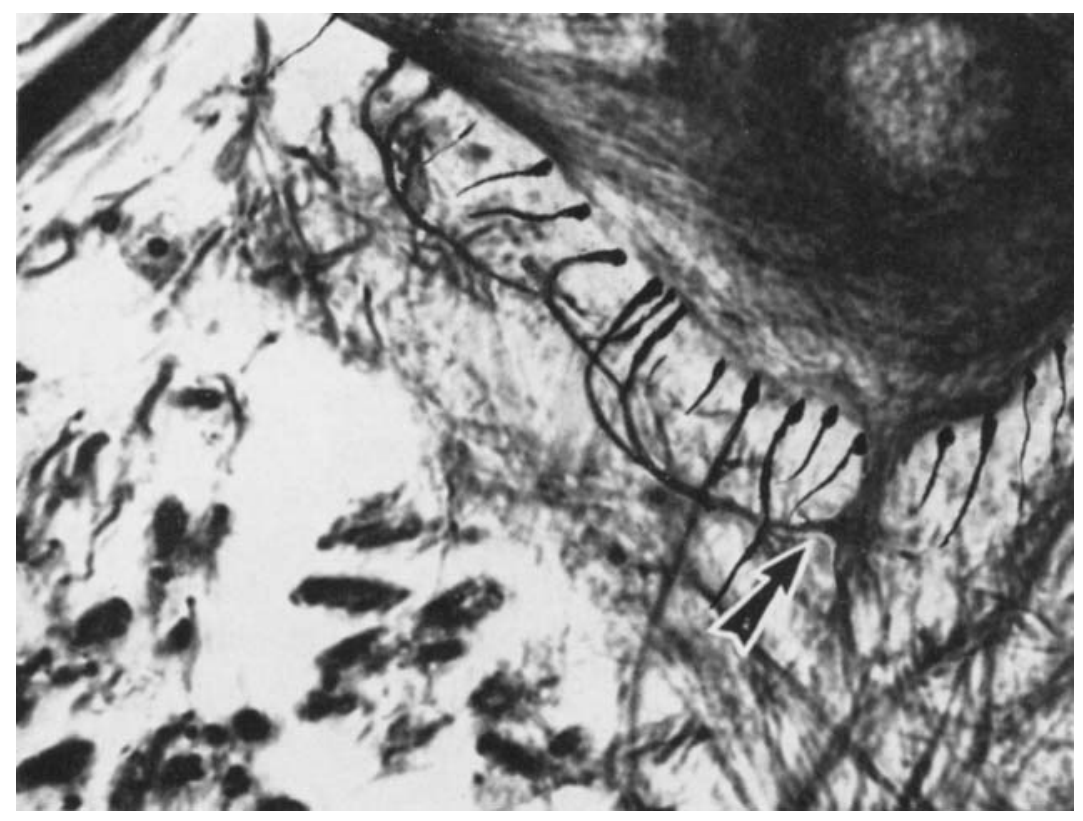

Fig. 7 Reenforcing collateral originating from the proximal portion of the axon (arrow) of a Müller's cell of the bullhead and ending with a series of boutons on the perikaryon and the dendrite of the same cell. The collateral and endings have been darkened. Freeze-dehydration, modified Bouin fixative, protargol stain. $\times 2100$. 


\section{Purkinje cells}

The Purkinje cells seen in a protargol-stained cerebellum of the dog and the cat have the typical form. The surface of these neurons appears to be smooth, except at the distal tips of the dendritic branchings, where a slight roughness is

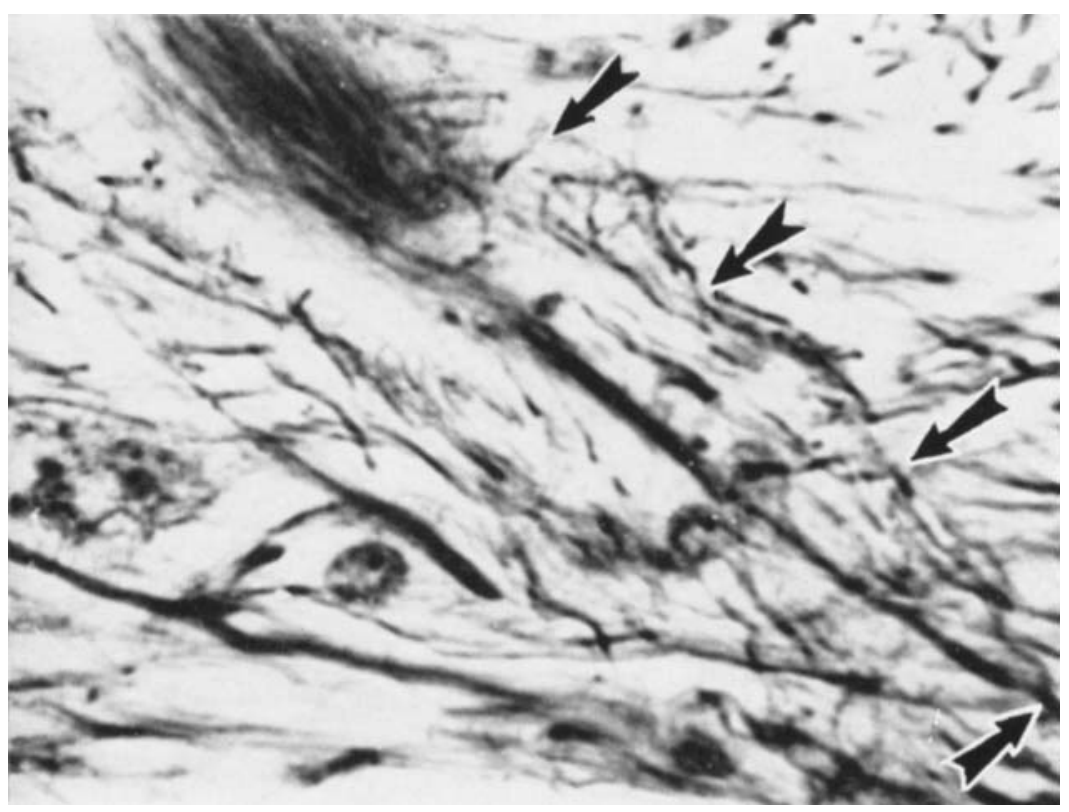

Fig. 8 Reenforeing collateral originating from the axon of a reticular cell of the bullhead and ending on a dendrite of the same cell. (Lower arrow indicates its origin and the upper arrow its synaptic ending.) Freeze-dehydration, modified Bouin fixative, protargol stain. $\times 1250$.

evident. They closely resemble the Purkinje dendrites shown in Golgi's Atlas (1894, pl. 11), but differ from those pictured by Ramón y Cajal ('11, p. 8). This is an example of an apparent structural difference in the same type of neurons when these are stained by different methods. The perikaryon and the dendrites stain a translucent blue or lavender, and the axon, a deep blue or purple. A short distance from the hillock the axon acquires a heavy myelin sheath. 
These massive dendrites may generate a powerful centrogenic current which, according to Gesell ('40), results from their high metabolic activity. Spontaneous electrical activity of the Purkinje cell and/or the granule cell layers in the form of both spikes and waves was reported by Brookhart

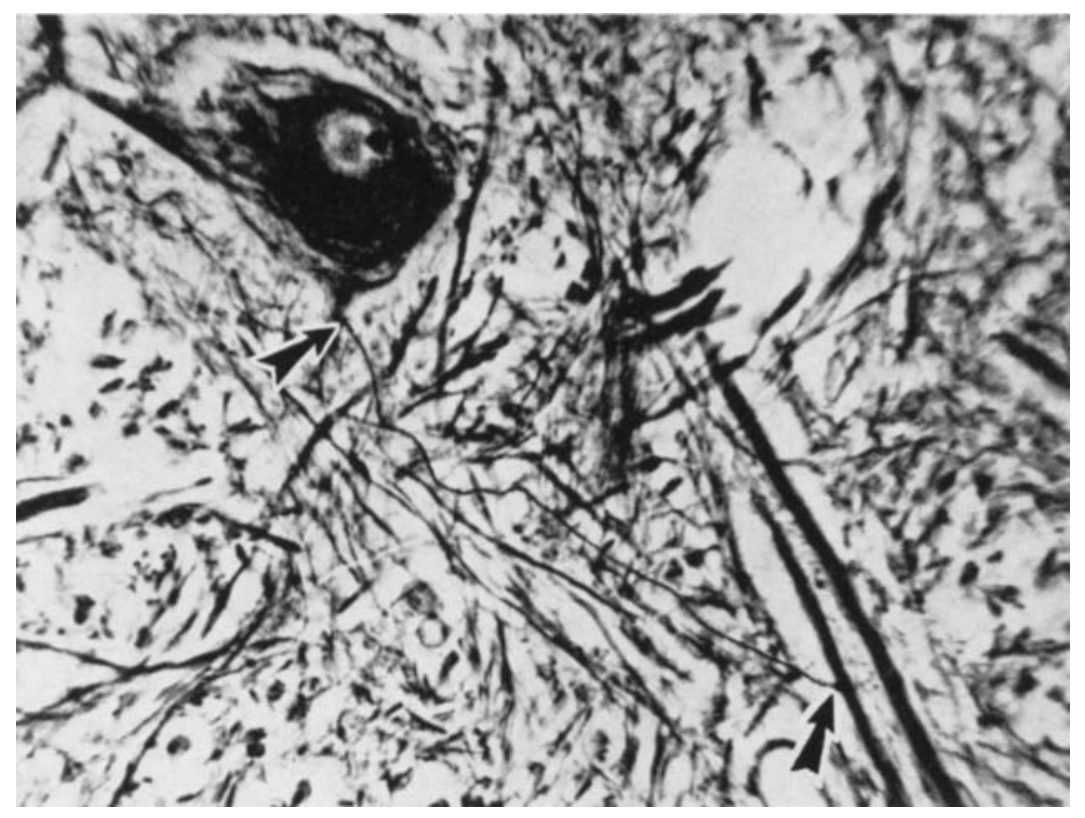

Fig. 9 Axon collateral from a descending axon (lower arrow) ends on the proximal portion of the axon of a reticular cell (upper arrow) of the bullhead. The collateral has been drawn from three adjacent sections. Freeze-dehydration, absolute alcohol-chloral hydrate fixative, protargol stain. $\times 1000$.

et al. ('51). This activity may be the constant centrogenic current originating from the Purkinje cells.

Bulb-like synaptic endings of collaterals of the basket-cell axon on both the axonic and the dendritic regions of the perikaryon are evident in our preparations. The basket-cell collaterals occasionally end on the cell body in a series (figs. 10,11 ), but single synaptic endings are more common. Ramón y Cajal ('11, p. 29) described collaterals of the axons of basket cells ending on the proximal portion of the axon 
of the Purkinje cells. In our slides the baskets enclosing the Purkinje cells appears to have fine terminal branchings which surround the axon pole, forming a cap similar to the axon cap of Mauthner's cells (figs. 11, 12). The fine terminal fibers sometimes extend for a short distance into the granular layer before turning back to wind around the proximal portion of the axon in the form of a spiral. These fibers end as minute synaptic bulbs on the Purkinje axon (figs. 11, 12). The distribution of synaptic endings to both the axon and dendrite

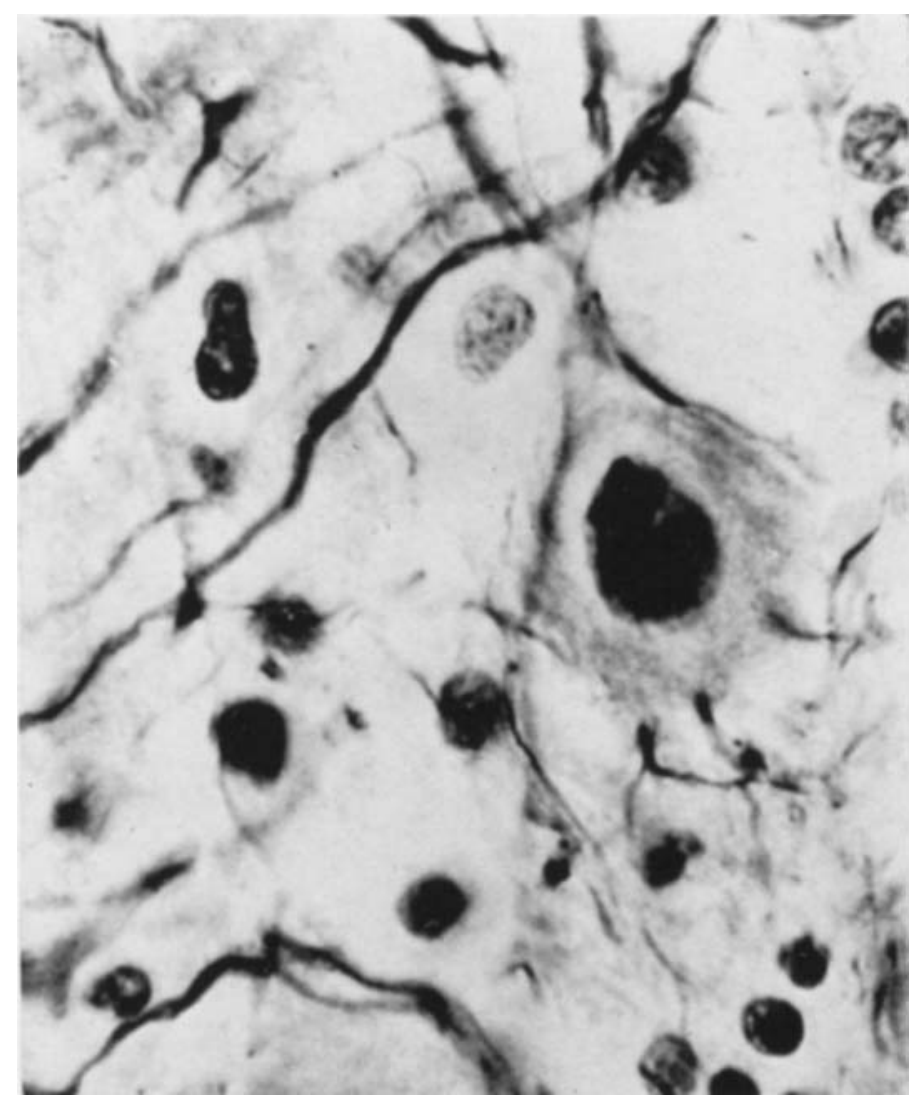

Fig. 10 Purkinje cell of dog. Note series of three synaptic endings of basketcell axon collateral at the axon pole of the cell body. Freeze-dehydration, absolute aleohol-chloral hydrate fixative, protargol stain. $\times 900$. 
poles of the cell body is in accord with Gesell's concept of the polar function of the neuron. Stimulation of the spinocerebellar and the cortico-ponto-cerebellar pathways results in the initiation, augmentation, or inhibition of cerebellar neuron activity (Brookhart et al., '51). This suggests that these afferents may affect the Purkinje cells in a polar manner, with the excitatory and augmentory afferents ending on the dendritic pole and the inhibitory afferents ending on or near the axon hillock.

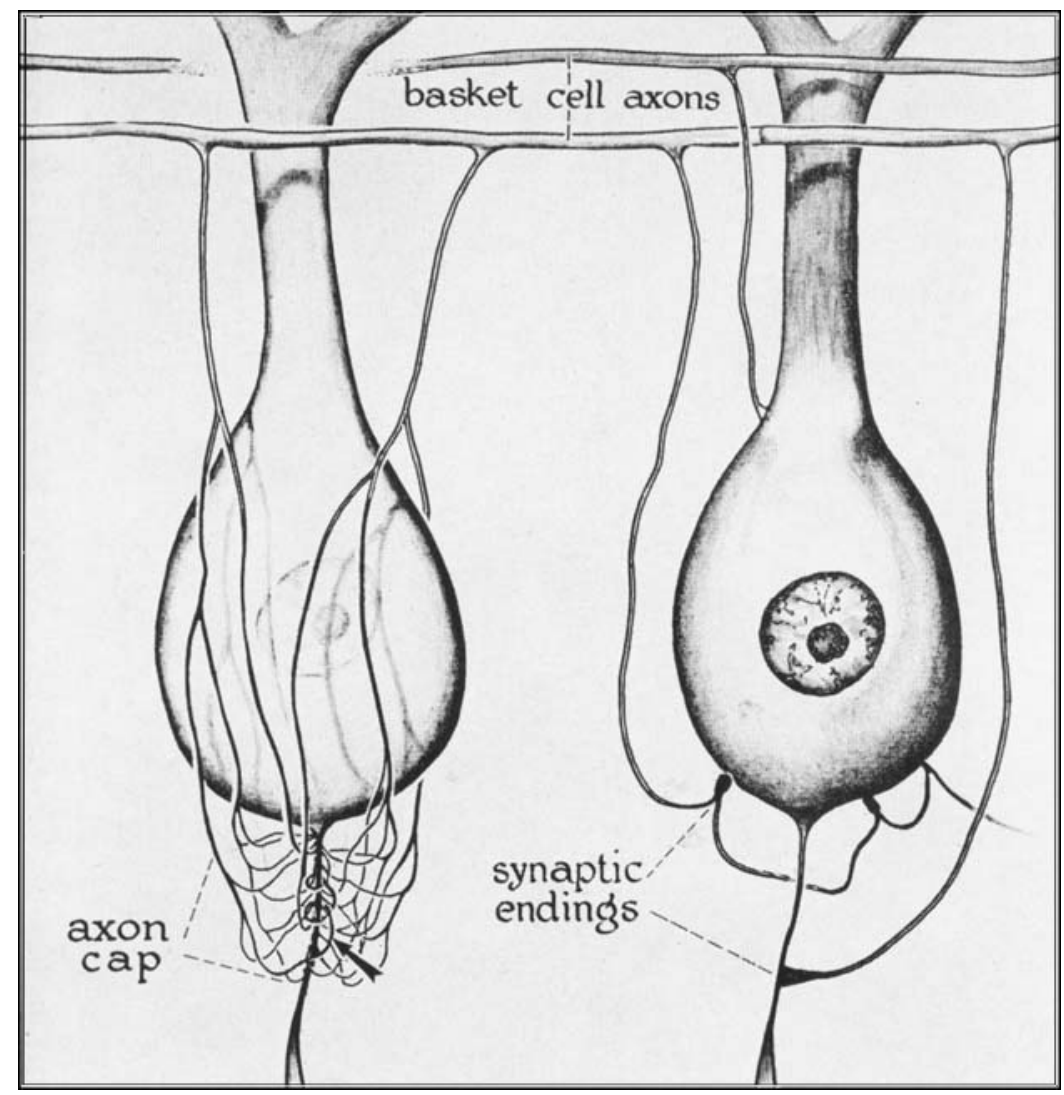

Fig. 11 Diagrammatic representation of Purkinje cells. Cell on right shows synaptic boutons of basket-cell axon collaterals ending in a series on the axon pole of the cell and a single ending on the axon. Cell on left shows an axon cap formed by basket-cell axon collaterals. Note the spiral (arrow) around the axon. 
Both the parallel fibers and the climbing fibers are generally accepted to be afferent pathways to the Purkinje cell dendrites. In our protargol-stained preparations of the dog. cortex, no actual contact of the parallel fibers with branchlets

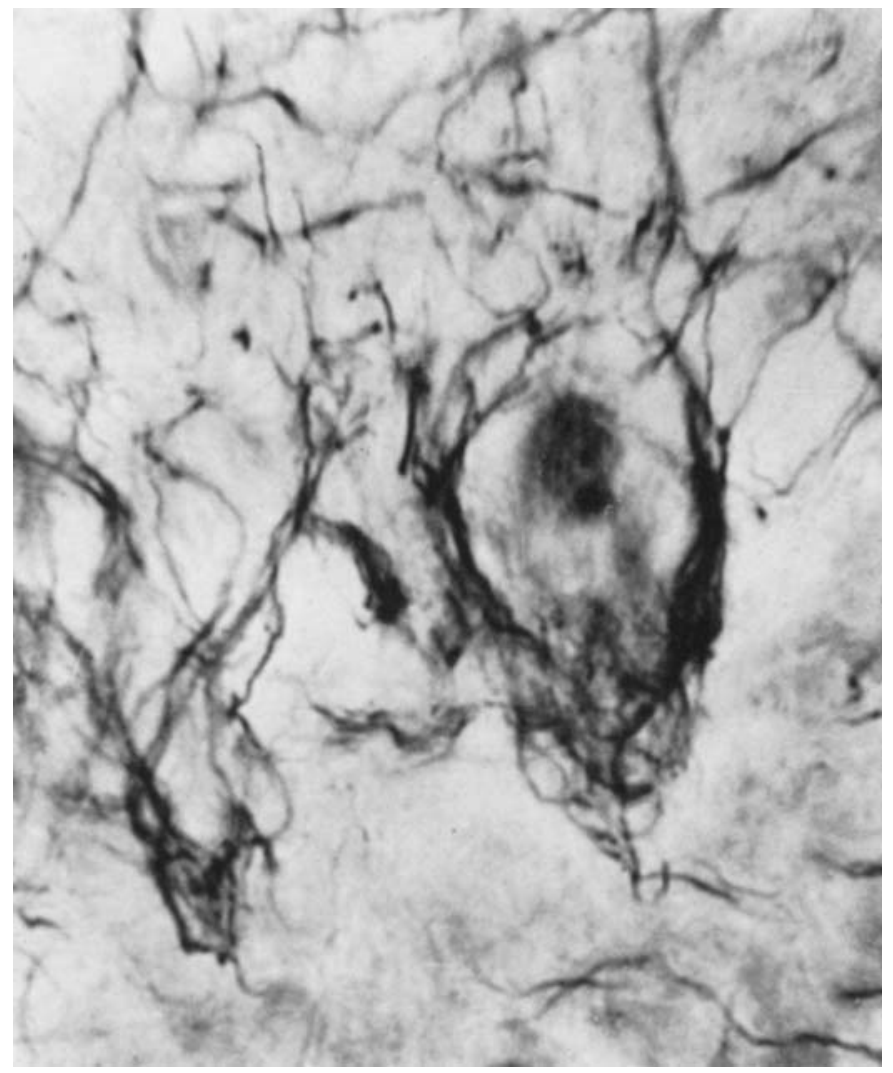

Fig. 12 Purkinje cell of dog, showing axon cap formed by basket-eell axon collaterals. Freeze-dehydration, modified Bouin fixative, protargol stain. $\times 1000$.

of the Purkinje dendrite is evident. However, it is generally accepted, as suggested by Ramón y Cajal ('11, p. 41), that the parallel fibers excite the Purkinje cells by contacting their dendritic branchlets as they course among them. Another means by which excitation may occur is by the genera- 
tion of an electrical field by the minute unmyelinated parallel fibers as they pass among the branchlets.

The climbing fibers closely follow the pattern of the Purkinje dendrites, but are not in intimate contact with them

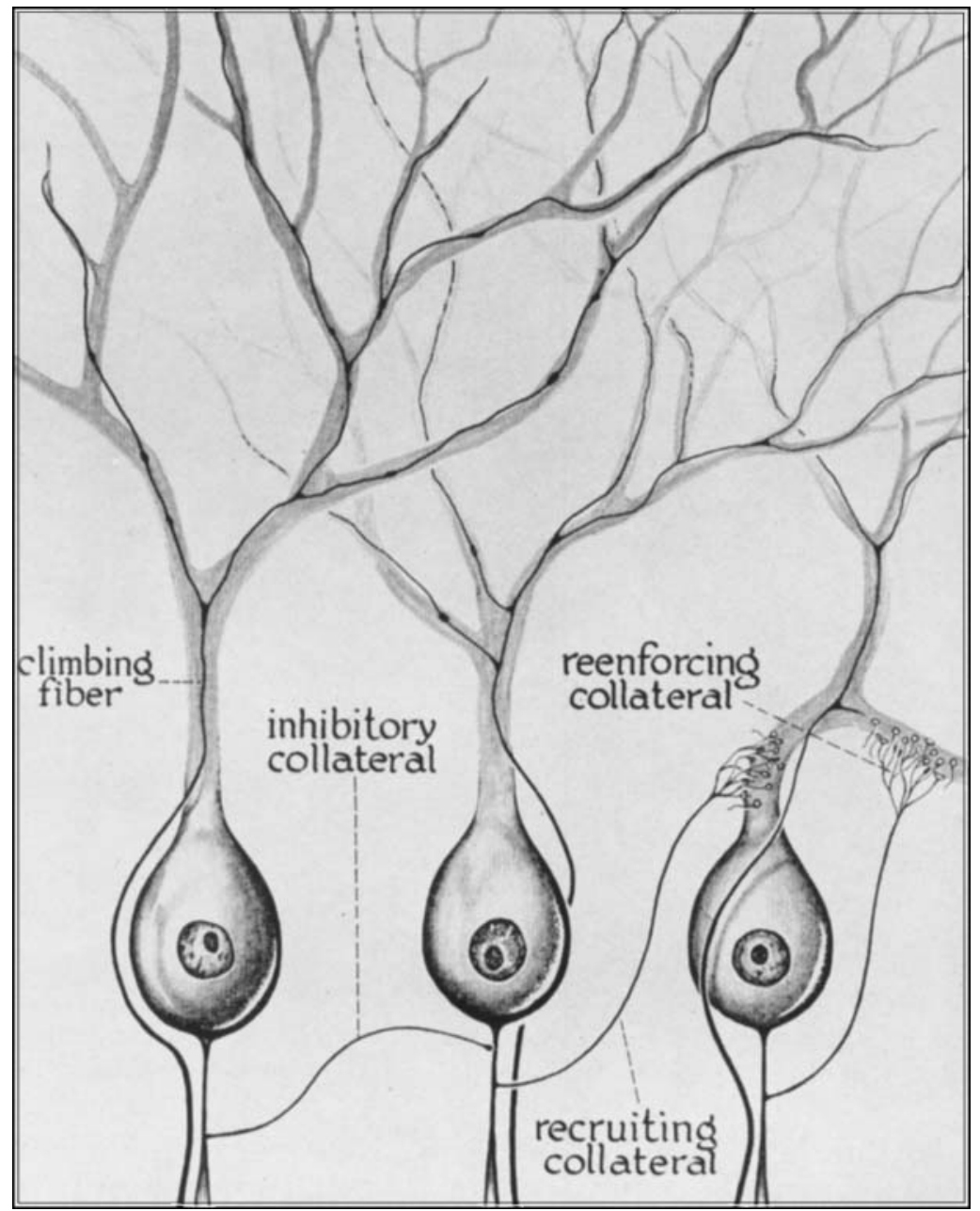

Fig. 13 Diagrammatic representation of three types of axon collaterals seen in relation to the Purkinje cells of the dog. These are the inhibitory collaterals, the recruiting collaterals and the reenforeing collaterals. 
for their entire length. In regions where they lie on the dendrite surface, slight enlargements occur at irregular intervals, which may represent contact-type synapses. Frequently these fibers will pass beyond the distal tips of the dendrites nearly to the cortical surface. There they turn and appear to end in relation to an adjacent dendrite. These fibers may excite the Purkinje cells by synaptic contact, or they, too, may generate an excitatory field around the dendrites.

Recurrent axon collaterals of Purkinje cells were described by Ramón y Cajal (' 11, p. 8). In our preparations, the three types (fig. 13) evident are the reenforcing collaterals, the recruiting collaterals, and the inhibitory collaterals, as suggested by Gesell ('40). The reenforcing collaterals originate from the axon and extend to the basal region of a dendrite of the same Purkinje cell, where they branch and then end with numerous loop-like terminal boutons in a spray-like pattern. Similar loop-like endings were demonstrated on the Purkinje cell dendrites by Ramón y Cajal ('11, p. 11), in his reduced-silver preparations of the dog cerebellum. The recruiting collaterals originate in a similar manner, but end upon a dendrite of an adjacent Purkinje cell. The inhibitory collaterals arise from the axon of one Purkinje cell; they terminate on the axon of an adjacent Purkinje cell, with a single terminal synaptic enlargement. The function of these collaterals may be the regulation of the discharge of the Purkinje neurons. Thus, the proposed excitatory role of the axo-dendritic collaterals is to increase the potential of the cell from which the axon arose by means of the reenforcing collaterals or to increase the potential of an adjacent Purkinje cell by the action of the recruiting collaterals. The inhibitory axo-axonic collaterals may act to prevent the discharge of a neighboring Purkinje cell. In the last case, two Purkinje cells may function as a neuron pair, with each cell affecting a motor neuron controlling an opposing action, thus supporting the half-center concept of Gesell. 
Cerebellar stimulation has been shown to produce localized movements, as well as to suppress or facilitate movements set up reflexly or through the cerebral cortex (Snider, '50). This suggests that paired neurons of the cerebellum may exert an effect on paired neurons in the motor cortex or in the spinal cord. This structural relationship offers an explanation as to the action of the cerebellum as the "great modulator of neurologic function," as proposed by Snider ('50).

\section{DISCUSSION AND SUMMARY}

According to Gesell's theory of the way in which the central nervous system functions, the dendrites and cell body of the neuron are considered to be dynamic generators of a relatively constant but subthreshold centrogenic current. This concept may be supported by the work of Brookhart and his associates ('51), in which they recorded spontaneous electrical activity in the form of both spikes and waves from the Purkinje cell and/or granule cell layers of the cerebellum. The activity of the cerebellum persists even after it has been deafferented (Spiegel, '37; Dow, '39; Snider and Eldred, ' 49 ; Brookhart et al., '50), which may also support the concept of neurocellular generation of centrogenic current. The massive dendrites of the Purkinje cells, believed to have a relatively higher metabolic rate than the axon hillock region, could be the source of this spontaneous activity. Other neurons reported to have a spontaneous discharge are the pyramidal cells of the motor cortex (Adrian and Moruzzi, '39) and the spinal motor neurons (Adrian and Bronk, '29). However, a higher spontaneous frequency is obtained from the cerebellar neurons (Brookhart et al., '50). The morphology of these neurons may explain their high-activity state. The actual dendritic mass of a Purkinje cell is far greater than that of either of the two types of motor neurons previously mentioned. It is possible that the centrogenic current generated by the Purkinje cells is at a near-threshold level at all times, and that the intracerebellar neuron connections provide the synaptic driving forces necessary to regulate the 
activity of the Purkinje cells even when the cerebellum is deafferented. Nevertheless, in the intact animal, the afferents may serve to moderate and to augment, as well as to inhibit, the Purkinje cell activity.

The synaptic boutons on the neurons may function as minute electrochemical generators of negativity which produce a fluctuating reflexogenic current (Gesell, '40). By the division of the neuron into an excitatory pole formed by the dendrites and the perikaryon, and an inhibitory pole consisting of the region adjacent to and including the axon hillock, the level of activity of the neuron may be determined by the quantitative variations in the synaptic reflexogenic current wherever it is applied to the neuron. Accordingly, when the sum of the synaptic forces is added to the centrogenic negative current, the potential-difference between the dendritic and axonic poles will change. When synaptic negativity is added at the excitatory pole, the potential-difference between the dendrites and axon hillock increases, and, if of threshold level, the neuron will discharge. However, when synaptic negativity is added at the inhibitory pole, the potential-difference decreases and the neuron then will be inhibited as demonstrated in recent experiments (Gesell and Dontas, '52a, $52 \mathrm{~b})$. Briefly stated, the postulated action of the synaptic endings on the dendrites and cell body is to cause excitation and their action on or near the axon hillock to cause inhibition of the neuron discharge. These suggest a polar function of the neuron (fig. 5).

It is evident that the dendritic and the axonic poles of the neuron differ in their chemical composition as is shown by the Nissl granule stain and by the acid phosphatase method of Gomori ('41). Nissl granules usually are distributed throughout the cytoplasm except in the axon hillock region. In contrast, the acid phosphatase reaction deeply stains the axon hillock and the proximal portion of the axon. In most of our preparations of central nervous system tissue processed by freeze-dehydration and stained by protargol, the dendrites and perikaryon stain a translucent blue or lavender but the 
axon hillock and proximal portion of the axon are colored a deep blue or purple.

These differential staining reactions suggest a cytoplasmic chemical polarity in conformity with the concept of polar function of the neuron. Possibly they are also correlated with other neuronal specializations such as generation of neurocellular current, changes in ionic permeability of the neuromembrane and the axon hillock phenomena of rhythmic response and of adaptation.

In the fish, a structural relationship between the VIIIth nerves and the Mauthner's cells may support the concept of polar function of the neuron. The VIIIth nerve root fibers appear to end mainly on the lateral dendrite and the perikaryon of the homolateral Mauthner's cell and the axon pole of the contralateral Mauthner's cell. The same type of relationship exists by an indirect connection of VIIIth nerve fibers with Mauthner's cells by way of the vestibular nuclei. Stimulation of the VIIIth nerve receptors can excite the homolateral Mauthner's cell, and at the same time inhibit the discharge of the contralateral cell via both direct and indirect pathways. This will give rise to simultaneous reflex excitation of one Mauthner's cell and inhibition of the other (fig. 3).

The three types of recurrent axon collaterals described in this paper serve to mediate and integrate the activity of the central nervous system. These are designated as reenforcing, recruiting, and inhibitory collaterals (fig. 13). The reenforcing and recruiting collaterals, which extend from the axon of one neuron, end on the perikaryon or dendrites of the same or an adjacent neuron, respectively. Their function is probably to increase the potential-drop of the neuron upon which they end, thus being excitatory in action. The inhibitory collaterals pass from the axon of one cell to the axon pole of an adjacent nerve cell. The function of these is to inhibit the neuron discharge by decreasing the potential-drop of the neuron upon which they end. Reenforcing collaterals of Müller's and reticular cells have been seen in our prepa- 
rations of fish brain (figs. 7,8 ). Inhibitory collaterals extend between the reticular cells in fish and between the pyramidal cells in dog (figs. 5, 6). All three types of collaterals are evident on the Purkinje cells of dog and cat (fig. 13).

Of particular interest is the axon cap of terminal axon branchings. These branchings form a spiral around the axon pole of spinal motor neurons and Mauthner's cell of fish (fig. 5), and on the Purkinje cells of the dog (figs. 11, 12) and the cat. These spirals may inhibit the neuron discharge not only by the action of their synapses, but also by the generation of an electrical field around the inhibitory pole.

Both the climbing fibers and the parallel fibers are generally regarded today as being neuraxons and as excitatory afferents to the Purkinje cells (Ranson and Clark, '47). Ramón y Cajal ('11, p. 41) described the parallel fibers contacting the Purkinje dendrite branchlets as they pass through the dendritic arborizations, and he suggested that they excite whole series of Purkinje cells. He apparently had not ascertained the function of the climbing fibers and suggested that they might not be neuraxons (Ramón y Cajal, '11, p. 71).

In our protargol-stained dog and cat tissue there is no indication of an intimate contact of the parallel fibers with the Purkinje branchlets as they course among them. This may be due to the branchlets being refractory to protargol, even though other neuronal elements appear to be completely impregnated. In the same tissue, the climbing fibers appear to wind around the Purkinje dendrites, but are not always closely applied to their surfaces. There are slight enlargements at irregular intervals along the climbing fibers at points where they lie in contact with the dendrites. These may be contact points which function as synapses. Another means by which the parallel and climbing fibers could affect excitation of the Purkinje cells would be by their generating an electrical field which would tend to increase the potentialdifference between the dendritic and the axonic poles of the neuron in the same manner as that suggested for synaptic endings on the dendrites. 
In conclusion, it may be said that the neurohistological evidence presented in this report lends support to the concepts of polar function of the neuron, the regulation of neuronal discharge by recurrent axon collaterals, and the organization of the central nervous system into neuron pairs, or half-centers.

\section{ACKNOWLEDGMENTS}

The author wishes to express his gratitude to Professor Robert Gesell for his guidance and encouragement, as well as for the excellent research facilities provided during the course of this investigation; and to Professor Elizabeth C. Crosby, for her valuable assistance and suggestions. He also wishes to thank Mr. Earl Bryant for constructing the special equipment used and Mr. Alfred Pepper for his technical assistance.

\section{LITERATURE CITED}

Adrian, E. D., AND D. W. Bronk 1929 The discharge of impulses in motor nerve fibers. II. The frequency of discharge in reflex and voluntary contractions. J. Physiol.,, 67 : 119-151.

Adrian, E. D., AND G. MoruzzI 1939 Impulses in the pyramidal tract. J. Physiol., 97: 153-199.

Ariëns Kappers, C. U., G. Cari Huber and Elizabeth C. Crosby 1936 The comparative anatomy of the nervous system of vertebrates, including man. 2 vols. McMillan, New York.

Bartrimez, G. W. 1915 Mauthner's cell and the nucleus motorius tegmenti. J. Comp. Neur., 25: 87-128.

Bartelmez, G. W., aNd N. L. HokrR 1933 The vestibular club endings in Ameiurus. Further evidence on the morphology of the synapse. J. Comp. Neur., 57 : 401-428.

BeCOARI, N. 1907 Ricerche sulle cellule e fibre del Mauthner e sulle loro connessioni in Pesci ed Anfibii. Arch. Ital. Anat. e Embriol., 6: 660-705.

Bodian, D. 1936 A new method of staining nerve fibers and nerve endings in mounted paraffin seetions. Anat. Rec., $65: 89-97$. 1937a The staining of paraffin sections of nervous tissue with activated protargol. The role of fixatives. Anat. Rec., 69: 153-162.

$1937 \mathrm{~b}$ The structure of the vertebrate synapse. A study of axon endings on Mauthner's cell and the neighboring centers in the goldfish. J. Comp. Neur., 68: 117-159.

Brookhart, J. M., G. Morvzzi AND R. S. SNider 1950 Spike discharges of single units in the cerebellar cortex. J. Neurophysiol., 13: 463-486.

1951 Origin of eerebellar waves. J. Neurophysiol., 14: 181-190.

Coghill, G. E. 1934 New anatomical relations and the probable function of Mauthner's fibers. Psychiat. en Neur. Bladen, 38: 386-391. 
Dow, R. S. 1939 Cerebellar action potentials in response to stimulation of various afferent connections. J. Neurophysiol., 2 : 543-555.

Gersh, I. 1932 The Altmann technique for fixation by drying while freezing. Anat. Rec., 53 : 309-337.

GESELL, R. 1940 A neurophysiological interpretation of the respiratory act. Ergebn. Physiol., 43: 477-639.

GeselL, R., AND A. S. Dontas 1952a Central inhibition: reflexly, reciprocally and chemically induced. Am. J. Physiol., 170: 690-701.

$1952 \mathrm{~b}$ An electrical study of manifestations of paired motor halfcenters (excitation, inhibition, precedence of stimulation, adaptation and rebound). Am. J. Physiol., 170: 702-716.

Glick, D., and Bo. G. MaImstrom 1951 Studies in histochemistry. XXIII. Simple and efficient freeze-debydration apparatus for the preparation of embedded tissue. Exp. Cell Researeh, 3: 124-135.

GolgI, C. 1894 Untersuchungen über den feineren Bau des centralen und peripherischen Nervensystems. (Atlas) Fisher, Jena, 30 pl., 31 1. fol.

Gomori, G. 1941 The distribution of phosphatase in normal organs and tissues. J. Cell. and Comp. Physiol., 17: 71-83.

Herrick, J. C. 1914 The medulla oblongata of larval Amblystoma. J. Comp. Neur., 24: $343-427$.

MaYser, P. 1882 Vergleichend-anatomische Studien über das Gehirn der Knochenfische mit besonderer Berïeksiehtigung der Cyprinoiden. Zeits. F. wiss. Zool., $36: 259-364$.

Mandelow, H., AND J. B. Hamiltow 1950 A new technique for rapid freezing and dehydration of tissues for histology and histochemistry. Anat. Rec., 107 : 433-451.

Petrunkevitch, A. 1943 Some curious effects of salts of metals and other chemicals on fixation. Anat. Rec., 86: 387-399.

Pitzorno, M. 1913 Ganglio ciliare die Selacei. Arch. Ital. Anat. e Embriol., 11: $527-535$.

1914 Contributo alla conos cenza della structura del ganglio ciliare dei Cheloni. Arch. Ital. Anat. e Embriol, 12: 367-379.

RAḾ́N Y CAJAL, S. 1911 Histologie du système nerveux de l'homme et des vertébrés. 993 pp. Maloine, Paris.

RANson, S. W., AND S. L. CLARK 1947 The anatomy of the nervous system. 8th ed. $532 \mathrm{pp}$. Saunders, Philadelphia.

RogERs, K. T. 1952 Optie nerve pattern evidence for fusion of eye primordia in cyclopia Fundulus heteroclitus. J. Exp. Zool., 120: 287-310.

SNIDER, R. S. 1950 Recent contributions to the anatomy and physiology of the cerebellum. Arch. Neur. and Psychiat., 64: 196-219.

SNIDER, R. S., AND E. ELDRED 1949 Maintenance of spontaneous activity within the cerebellum. Proc. Soc. Exp. Biol., N. Y., 72: 124-127.

SpIEger, E. A. 1937 Comparative study of thalamic, cerebral and cerebellar potentials. Am. J. Physiol., 118: 569-579. 
PLATE 1

EXPLANATION OF FIGURES

14 Transverse section of Mauthner's cell of the bullhead showing the axon hillock at the upper left and the two ventral dendrites extending downward. Note the synaptic endings on all surfaces of the perikaryon, on the eap-dendrite and on the axon hillock. Freeze-dehydration, modified Bouin fixative, protargol stain. $\times 900$.

15 Longitudinal section through Mauthner's cell of the goldfish. Both small and large end-feet are evident on the surface of the perikaryon. Freeze-dehyrdation, protargol stain with acridine yellow counterstain. $\times 1800$. 

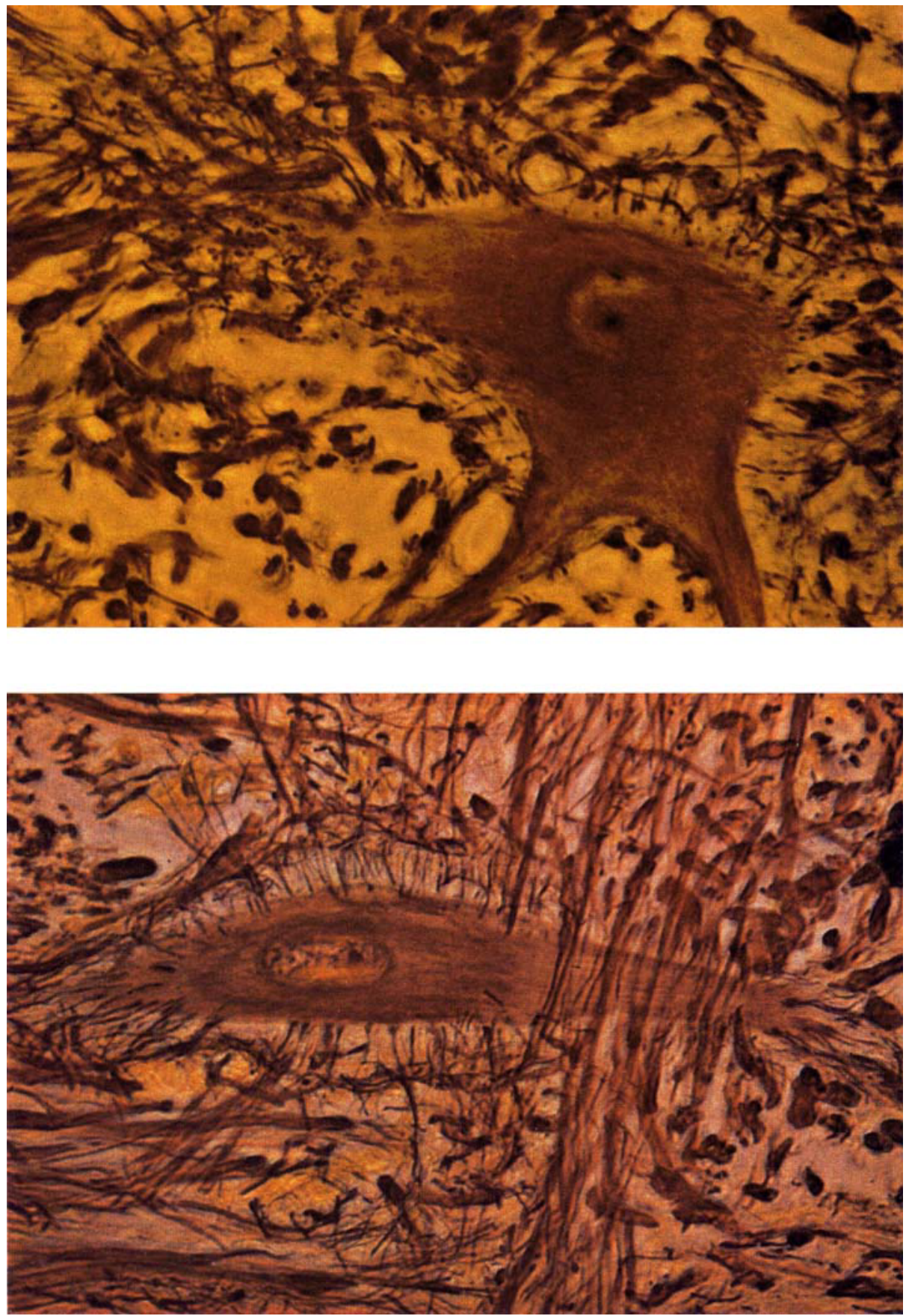